\title{
A STUDY ON WATER VAPOUR PERMEABILITY WITH INCREASED FUNCTIONAL PROPERTIES OF UPPER LEATHERS
}

\author{
Victor JOHN SUNDAR*, Chellappa MURALIDHARAN \\ Leather Process Technology Division, Adyar, Chennai - 600 020, India \\ Accepted: 18.05.2017 \\ https://doi.org/10.24264/Ifj.17.3.5
}

Received: 20.04.2017

\section{A STUDY ON WATER VAPOUR PERMEABILITY WITH INCREASED FUNCTIONAL PROPERTIES OF UPPER LEATHERS}

ABSTRACT. Water vapour permeability is one of the most important physical properties of leathers, which impacts the essential functional properties such as the breathability and the comfort of leather products. With growing stringent requirements for sports footwear this property gains added significance. In this work an attempt has been made to enhance the water vapour permeability for upper leathers by opening up the fibre structure and designing suitable tanning and post tanning processes. The objective of improving water vapor permeability through enzymatic and chemical methods has been achieved without affecting other mechanical properties of leathers. Thermoporometry results too confirmed the water vapour permeability was improved positively with enzymatic and chemical treated leathers. The major finding is the differences in water vapour permeability between crust and finished leathers were minimal.

KEY WORDS: leather, water vapour permeability, footwear

\section{STUDIU PRIVIND EFECTUL PERMEABILITĂTII LA VAPORI DE APĂ ASUPRA ÎMBUNĂTĂTIRII PROPRIETĂTILOR FUNCTIONALE ALE PIEILOR PENTRU FETE ÎNCĂLTĂMINTE}

REZUMAT. Permeabilitatea la vaporii de apă este una dintre cele mai importante proprietăţi fizice ale pieilor, care influenţează proprietăţi funcţionale esenţiale, cum ar fi respiraţia şi confortul produselor din piele. Având în vedere cerinţele din ce în ce mai stringente pentru încălţămintea sportivă, această proprietate capătă o importanţă şi mai mare. În această lucrare s-a încercat creşterea permeabilităţii la vaporii de apă pentru pielea destinată feţelor de încălţăminte prin deschiderea structurii fibrelor şi prin conceperea unor procedee adecvate de tăbăcire şi post-tăbăcire. Obiectivul de a îmbunătăţi permeabilitatea la vaporii de apă prin metode enzimatice şi chimice a fost realizat fără a afecta alte proprietăţi mecanice ale pieilor. Rezultatele termoporometriei confirmă că permeabilitatea la vaporii de apă a fost îmbunătăţită în cazul pieilor tratate enzimatic şi chimic. Principala constatare este că diferenţele de permeabilitate la vaporii de apă dintre pielea crust şi cea finită au fost minime.

CUVINTE CHEIE: piele, permeabilitate la vapori de apă, încălţăminte

\section{UNE ÉTUDE SUR LA PERMEABILITÉ À LA VAPEUR D’EAU POUR AUGMENTER LES PROPRIÉTÉS FONCTIONNELLES DES TIGES CUIR}

RÉSUMÉ. La perméabilité à la vapeur d'eau est l'une des propriétés physiques les plus importantes des cuirs, qui affecte les propriétés fonctionnelles essentielles telles que la respirabilité et le confort des produits en cuir. Compte tenu des exigences de chaussures de sport de plus en plus strictes, cette propriété acquiert encore plus d'importance. Dans cet article, on a essayé l'augmentation de la perméabilité à la vapeur d'eau du cuir pour tiges chaussures par l'ouverture de la structure fibreuse et en développant des méthodes appropriées de tannage et de post-tannage. L'objectif d'améliorer la perméabilité à la vapeur d'eau par des procédés chimiques et enzymatiques a été atteint sans affecter les autres propriétés mécaniques du cuir. Les résultats de la thermoporométrie confirment que la perméabilité à la vapeur d'eau a été améliorée dans le cas des cuirs au traitement enzymatique et chimique. La principale conclusion est que les différences de perméabilité à la vapeur d'eau entre le cuir en croûte et le cuir fini ont été minimes.

MOTS CLÉS: cuir, perméabilité à la vapeur d'eau, chaussures.

\section{INTRODUCTION}

Leather is an unique material that has the ability to absorb water vapor, transmit through its cross section and permeate into the atmosphere. This unique characteristic of leather offers comfort to the wearer of shoes in hot and humid conditions. In addition upper leathers should possess comfort properties, strength properties, functional properties and aesthetic properties.
Under normal conditions, 5 gms/hour sweat is produced by a human when the temperature condition is between 30 and $35^{\circ} \mathrm{C}$. Under industrial working condition, the sweat produced by a human foot is around $10 \mathrm{gms} /$ hour. Leather footwear has the ability to absorb the sweat produced and transmit to the upper part of the leather through wicking process which is known as water vapour permeability or water vapour

\footnotetext{
* Correspondence to: Victor JOHN SUNDAR, Leather Process Technology Division, CSIR-Central Leather Research Institute, Adyar, Chennai-600020, Tamil Nadu, India, e-mail: johnsundar70@yahoo.co.uk
} 
transmission [1]. Water vapour permeability is the ability of leathers allowing water vapour to transfer through from higher humid condition to lower humid condition [2]. This characteristic mainly depends on the porosity characteristic of leather. The ability to transmit water vapour is one of the important properties of leather that makes it most desirable for shoe making.

There are plenty of capillaries among collagen fibres in leathers as well as a lot of hydrophilic groups on the collagen chains. They may endow leathers with good water vapour permeability, compared with other synthetic materials [3]. Water vapour permeability is the volume of permeating water vapour in unit time and unit area, its unit is $\mathrm{mg} / 10 \mathrm{~cm}^{2} \mathrm{~h}$. The property depends upon a number of factors including porosity, thickness of leather, grease content and the relative humidity and temperature of the atmosphere [4]. It is greatly reduced by the presence of the natural glyceride greases. The solution is to remove natural fat during degreasing process with chemicals which do not affect the water absorbency. The finish on the grain layer also has an influence on water vapour transmission. Although leathers have a certain degree of water vapour permeability, improved water vapour permeability is required for special purposes such as application in sports shoes. Hence a study is undertaken to improve water vapour permeability without affecting those strength properties required for upper leather $[5,6]$.

\section{MATERIALS AND METHODS}

\section{Materials}

Fresh wet salted goat skins (24"$\left.28^{\prime \prime}\right)$ without any hair slip were chosen for experiments. Commercial grade protease and lipase (with activity in the range of $80-100$ TU), urea and acetic acid were chosen for experiments.

\section{Processing Methods}

Two pronged approach has been attempted to achieve enhanced water vapour permeability of skins viz., extensive enzymatic treatment during pre-tanning and treatment with lyotropic agents after chrome tanning.

\section{Liming}

The purpose of liming is to remove hair, epidermis, natural fats and greases, interfibrillary proteins, to swell and split up the fibre bundles, to soften the collagen fiber lattice and make the final leather soft and pliable. Conventional sulphide unhairing methods often do not yield clean pelt leaving residual scud which hinders the permeation. But enzymatic unhairing using proteolytic enzymes helps in complete removal of hair from its follicle yielding clean pores so that permeability of water vapor is enhanced. Enzymes are biocatalyst, hence they are specific in their action and they act specifically at the hair follicle and remove hair in shorter duration [7-9].

\section{Bating}

The objective of bating the delimed pelts with proteolytic enzymes is to remove non leather making substance and to make the grain surface clean, smooth and fine. The purpose is to remove the hair roots, break down of the non-structural proteins and to get clean pelt. The efficiency of bating depends on temperature, concentration, $\mathrm{pH}$ and duration. The experiment is carried out with varying concentrations of enzyme. The physical tests were performed at crust and finished leather stages.

\section{Degreasing}

Degreasing is the process of removing natural fat present in between the collagen fibers. If this fat is not removed completely, it affects the water vapour transmission in the final leather apart from forming fat spew. Conventionally huge amounts of solvents and surfactants are used for this challenging process. During the present study, lipase was used which acts specifically on lipids and frees the pores from blockage which enhances the permeation of water vapor.

\section{Treatment of Chrome Tanned Leathers}

When chrome tanned leathers are treated with lyotropic agents like urea $\left(\mathrm{CH}_{4} \mathrm{~N}_{2} \mathrm{O}\right)$, and acetic acid $\left(\mathrm{CH}_{3} \mathrm{COOH}\right)$ hydrogen bonds are broken and cementing substances held by the fiber bundles are removed. The quantities of the chemicals were optimized after several experiments. 


\section{Determination of Water Vapour Permeability}

Leather sample test specimens were taken from the official sampling position (ISO 2418) and were conditioned for 48 hours at $20^{\circ} \mathrm{C} \pm 2{ }^{\circ} \mathrm{C}$ and $65 \pm 2 \% \mathrm{RH}$ (ISO 2419). The leather sample under test is sealed on the mouth of a desiccant (dry silica gel) filled jar that provides a less humid gradient across the test sample and outside. The test jars sealed with dry silica gel held in a vertical wheel which rotates during the test. A large fan is also incorporated within the equipment, and this rotates in the opposite direction to the sample wheel. This creates air turbulence over the samples sealed in the mouth of the jar, thus removing the layer of still air. The sealed jars are weighed before and after test, and the increase in weight of desiccant is used to calculate the WVP of the sample, usually expressed as milligrams of water vapor per square centimeter per hour. The water vapour permeability tests were done for dyed crust leathers and for finished leathers [10-12].

\section{Determination of Tensile Strength and Elongation at Break}

The tensile strength, \% elongation, tear strength and grain crack strength were measured as per official procedures (SLTC Methods, 1965). The test specimens were conditioned for 48 hours at $20^{\circ} \mathrm{C} \pm 2^{\circ} \mathrm{C}$ and $65 \pm 2 \% \mathrm{RH}$. Strength characteristics of the leathers were tested for tensile strength and tongue tear strength tests in a Universal Instron testing machine (Instron 4501, England). A crosshead speed of $100 \pm 20$ $\mathrm{mm} / \mathrm{min}$ was used and the distance between the supports was $40 \mathrm{~mm}$. A load was applied to the center of the samples until fracture occurred and the fracture load was recorded.

The crust leathers were also tested for grain crack and grain burst using a lastometer (SATRA 1992). The test specimen was tightly clamped between the circular rings facing grain side upwards and the machine started by forcing the plunger at the rate of $0.2 \pm 0.05 \mathrm{~mm} / \mathrm{s}$. The surface of the specimen was continuously observed at the center for initial crack on the grain and the maximum distance and force were recorded.

\section{Capillary Flow Porometry Analysis}

PMI capillary flow porometer was used in this study to analyze the pore size and its distribution. The experimental and conventionally processed leather samples from different locations of crust leathers were cut into $20 \mathrm{~mm}$ diameter and the thickness was noted. Calwick with a defined surface tension of 15.9 dynes $\mathrm{cm}^{-1}$ was used as wetting liquid for porometry measurements. In this technique, at first a non-reacting gas was sent through a dry sample. Second, the same sample was wetted with liquid of known surface tension, through which the above mentioned gas was sent. The changes in flow rate were measured as a function of pressure for both dry and wet processes. The samples which had better water vapour permeability are chosen for wet and dry profiles (pressure vs. gas flow rate) which are measured for porosity.

\section{Scanning Electron Microscope}

The fibre structure of the control and experimental leathers have been studied using SEM analysis. Leather samples were coated with gold using an Edwards E 306 Sputter coater and analyzed by a Cambridge stereoscan S 150 scanning electron microscope.

\section{RESULTS AND DISCUSSIONS}

Water vapour permeability of control and experimental crust and finished leathers are shown in Table 1 and Table 2. According to the results, the leathers undergone enzymatic dehairing and bating processes have improved water vapour permeability compared to conventionally processed leathers. The better opening up of fibre structure by proteases may be the reason for more water vapour transmission without affecting strength properties. The best degreasing effect was obtained with the use of lipase alone. The effective saponification of natural greases increased the water vapor permeability compared to conventional surfactant based degreasing. When chrome tanned leathers were treated with unionized acetic acid, it attaches as a molecule to the collagen chains breaking the hydrogen bonds present in the collagen and thus resulting in fibre splitting. The treatment of skin matrix by urea 
has been proved to affect mainly the non ionic links like peptide group and breaks the hydrogen bond. Urea and acetic treatments improved water vapor permeability considerably. The water vapour permeability of experimental crust and finished leathers are better when compared with conventionally processed leathers. Even though surface finish coatings affect the water permeability, the effect was found to be negligible. The porosity parameters described in Figure 1 indicate the leathers which have undergone integrated treatment with acetic acid and urea have better porosity compared to conventional leathers.

Table 1: Water vapor permeability and physical characteristics of crust leathers

\begin{tabular}{|c|c|c|c|c|c|c|c|}
\hline \multirow{2}{*}{$\begin{array}{l}\mathrm{S} \\
\text { No }\end{array}$} & \multirow{2}{*}{ Experiments } & \multicolumn{2}{|c|}{$\begin{array}{l}\text { Water vapor permeability } \\
\qquad\left(\mathrm{mg} / \mathrm{cm}^{2} / \mathrm{hr}\right)\end{array}$} & \multicolumn{2}{|c|}{ Tensile strength $\left(\mathrm{N} / \mathrm{mm}^{2}\right)$} & \multicolumn{2}{|c|}{ Elongation at break $(\mathrm{mm})$} \\
\hline & & Control & Experiment & Control & Experiment & Control & Experiment \\
\hline \multicolumn{8}{|c|}{ Enzymatic interventions } \\
\hline 1 & Unhairing & $9 \pm 0.5$ & $12 \pm 0.5$ & $21 \pm 0.5$ & $31 \pm 0.5$ & $76 \pm 0.5$ & $88 \pm 0.5$ \\
\hline 2 & Bating & $7 \pm 0.5$ & $10 \pm 0.5$ & $25 \pm 0.5$ & $32 \pm 0.5$ & $74 \pm 0.5$ & $87 \pm 0.5$ \\
\hline 3 & Degreasing & $9 \pm 0.5$ & $12 \pm 0.5$ & $21 \pm 0.5$ & $29 \pm 0.5$ & $78 \pm 0.5$ & $89 \pm 0.5$ \\
\hline \multicolumn{8}{|c|}{ Chemical methods } \\
\hline 4 & Acetic acid treatment & $8 \pm 0.5$ & $11 \pm 0.5$ & $24 \pm 0.5$ & $34 \pm 0.5$ & $76 \pm 0.5$ & $89 \pm 0.5$ \\
\hline 5 & Urea treatment & $10 \pm 0.5$ & $13 \pm 0.5$ & $24 \pm 0.5$ & $29 \pm 0.5$ & $77 \pm 0.5$ & $89 \pm 0.5$ \\
\hline \multicolumn{8}{|c|}{ Integrated experiments } \\
\hline 6 & $\begin{array}{c}\text { Integrated - Acetic acid } \\
\text { treatment }\end{array}$ & $11 \pm 0.5$ & $18 \pm 0.5$ & $23 \pm 0.5$ & $33 \pm 0.5$ & $75 \pm 0.5$ & $86 \pm 0.5$ \\
\hline 7 & $\begin{array}{l}\text { Integrated - Urea } \\
\text { treatment }\end{array}$ & $15 \pm 0.5$ & $20 \pm 0.5$ & $24 \pm 0.5$ & $35 \pm 0.5$ & $78 \pm 0.5$ & $89 \pm 0.5$ \\
\hline
\end{tabular}

Table 2: Water vapor permeability of finished leathers

\begin{tabular}{|c|c|c|c|}
\hline \multirow{2}{*}{ S. No } & \multirow{2}{*}{ Experiment } & \multicolumn{2}{|c|}{ Water vapor permeability $\left(\mathrm{mg} / \mathrm{cm}^{2} / \mathrm{hr}\right)$} \\
\hline & & Control & Experiment \\
\hline \multicolumn{4}{|c|}{ Enzymatic interventions } \\
\hline 1 & Unhairing & $7 \pm 0.5$ & $10 \pm 0.5$ \\
\hline 2 & Bating & $6 \pm 0.5$ & $9 \pm 0.5$ \\
\hline 3 & Degreasing & $7 \pm 0.5$ & $9 \pm 0.5$ \\
\hline \multicolumn{4}{|c|}{ Chemical methods } \\
\hline 4 & Acetic acid treatment & $7 \pm 0.5$ & $10 \pm 0.5$ \\
\hline 5 & Urea treatment & $7 \pm 0.5$ & $12 \pm 0.5$ \\
\hline \multicolumn{4}{|c|}{ Integrated experiments } \\
\hline 6 & Integrated - Acetic acid treatment & $8 \pm 0.5$ & $14 \pm 0.5$ \\
\hline 7 & Integrated - Urea treatment & $12 \pm 0.5$ & $15 \pm 0.5$ \\
\hline
\end{tabular}

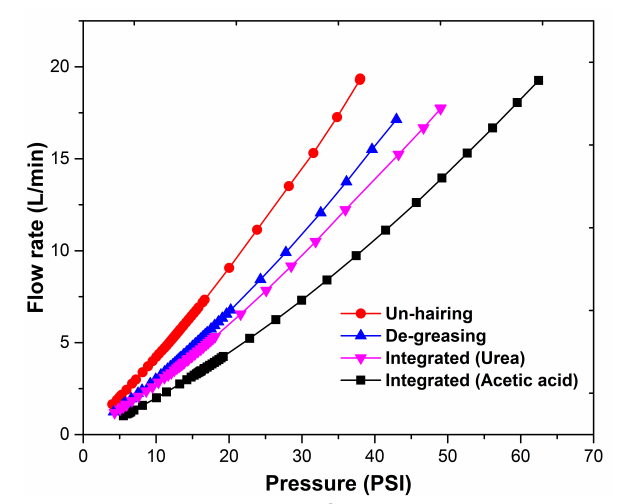

Figure 1. Porosity of experimental leathers 
The physical testing characteristics of the crust leathers indicate that strength properties such as tensile, tear, grain crack are comparable for experimental and conventional leathers (Table 3).

Table 3: Physical characteristics of experiments

\begin{tabular}{|c|c|c|c|c|c|c|c|}
\hline \multirow[t]{2}{*}{ S. No } & \multirow[t]{2}{*}{ Experiments } & \multicolumn{2}{|c|}{ Tear Strength $(\mathrm{N})$} & \multicolumn{2}{|c|}{ Load at grain crack $(\mathrm{N})$} & \multicolumn{2}{|c|}{$\begin{array}{l}\text { Distension at grain crack } \\
\qquad(\mathrm{mm})\end{array}$} \\
\hline & & Control & Experiment & Control & Experiment & Control & Experiment \\
\hline \multicolumn{8}{|c|}{ Enzymatic interventions } \\
\hline 1 & Unhairing & $41 \pm 2$ & $44 \pm 2$ & $205 \pm 6$ & $213 \pm 6$ & $8 \pm 0.5$ & $9 \pm 0.5$ \\
\hline 2 & Bating & $41 \pm 2$ & $44 \pm 2$ & $213 \pm 6$ & $220 \pm 6$ & $7 \pm 0.5$ & $8 \pm 0.5$ \\
\hline 3 & Degreasing & $42 \pm 2$ & $43 \pm 2$ & $208 \pm 6$ & $213 \pm 6$ & $7 \pm 0.5$ & $7 \pm 0.5$ \\
\hline \multicolumn{8}{|c|}{ Chemical methods } \\
\hline 4 & Acetic acid treatment & $41 \pm 2$ & $43 \pm 2$ & $205 \pm 6$ & $215 \pm 6$ & $7 \pm 0.5$ & $7 \pm 0.5$ \\
\hline 5 & Urea treatment & $41 \pm 2$ & $42 \pm 2$ & $203 \pm 6$ & $210 \pm 6$ & $7 \pm 0.5$ & $7 \pm 0.5$ \\
\hline \multicolumn{8}{|c|}{ Integrated experiments } \\
\hline 6 & $\begin{array}{c}\text { Integrated - Acetic acid } \\
\text { treatment }\end{array}$ & $41 \pm 2$ & $42 \pm 2$ & $205 \pm 6$ & $215 \pm 6$ & $7 \pm 0.5$ & $7 \pm 0.5$ \\
\hline 7 & $\begin{array}{l}\text { Integrated - Urea } \\
\text { treatment }\end{array}$ & $41 \pm 2$ & $43 \pm 2$ & $204 \pm 6$ & $213 \pm 6$ & $7 \pm 0.5$ & $7 \pm 0.5$ \\
\hline
\end{tabular}

From the Scanning Electron micrographs (Figures 3.1-3.14), it is clear that the experimental leather fibres were separated from one another, but in the case of control leather fiber aggregates could be noticed ( $2.1 \& 2.2$ ). In addition, SEM of the cross section of the enzymatic dehairing and bating processed experimental leather fibers showed a significant opening up of fiber bundles (Figures $3.2 \& 3.4$ ) and fine grain surface (Figures

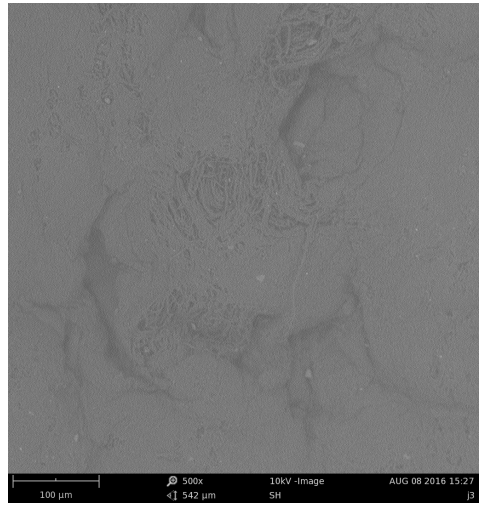

1. Grain surface - Control
3.1 \& 3.3). It was also observed that the SEM of the samples of acetic acid treatment and urea treatment has a smooth fiber, firmness grain and modified handle, which are good evidence of better water vapour permeability. The results indicate that experimental leathers have more and uniform fibre splitting as compared to that of conventional leathers.

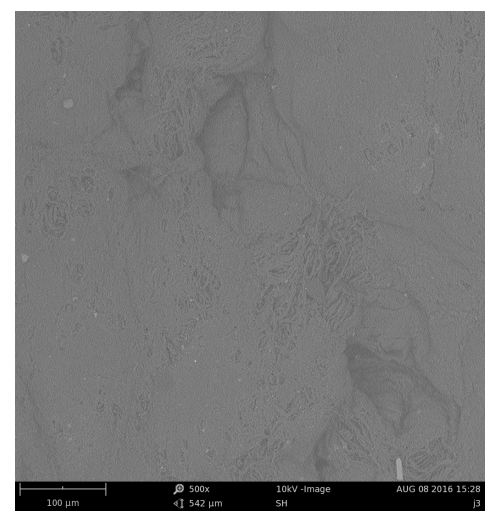

2. Cross section - Control

Figure 2. SEM of Control leathers 


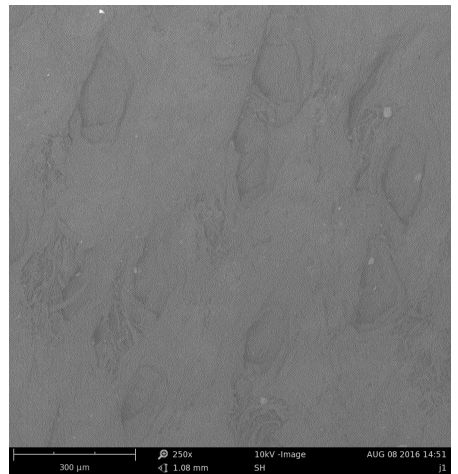

1. Grain surface - Unhairing Experiment

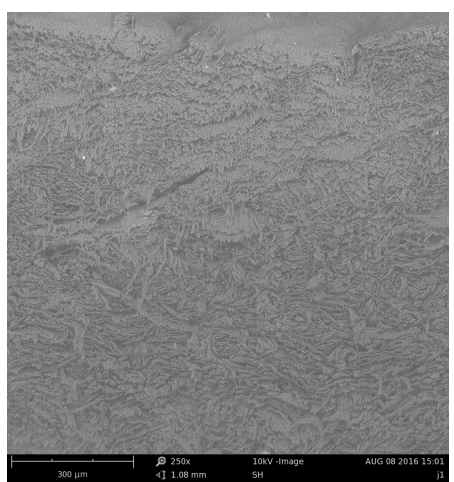

3. Grain surface - Bating Experiment

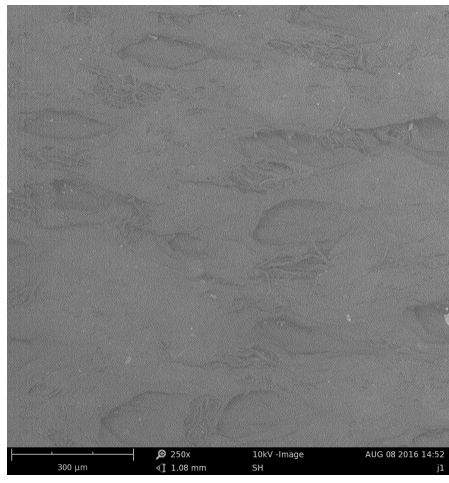

5. Grain surface - Degreasing Experiment

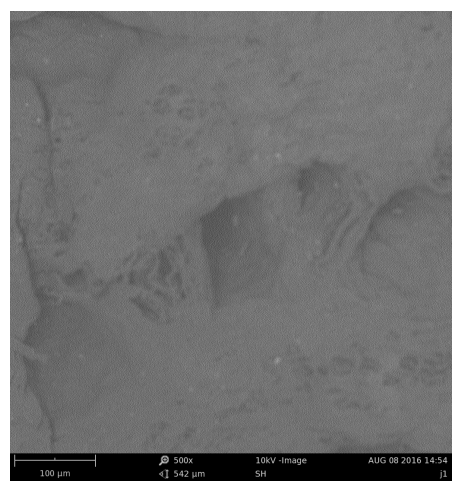

7. Grain surface - Acetic acid treatment Experiment

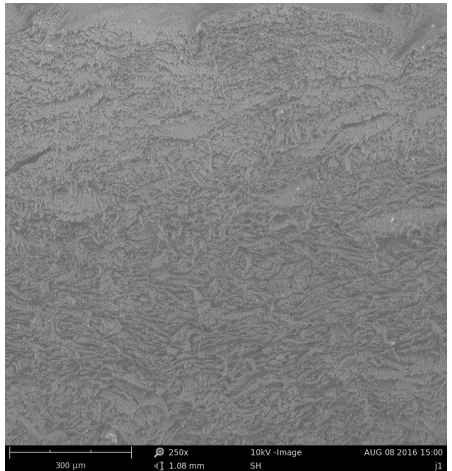

2. Cross section - Unhairing Experiment

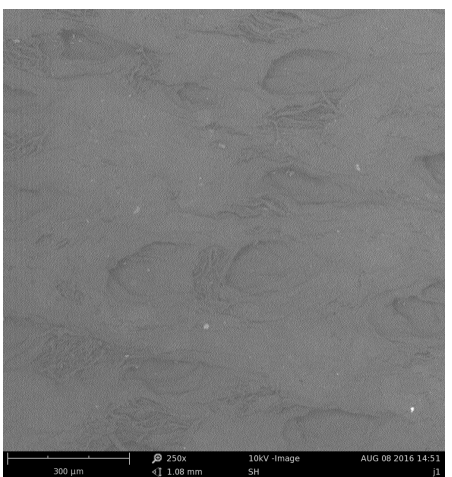

4. Cross section - Bating Experiment

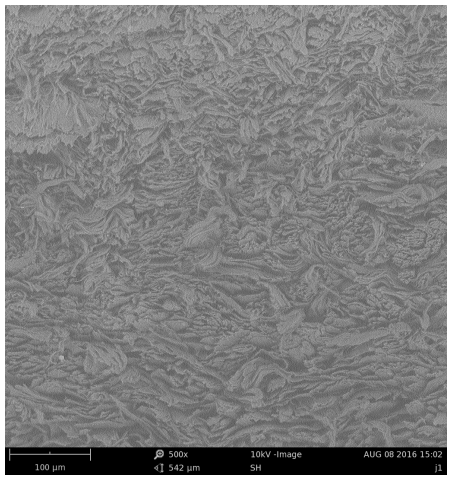

6. Cross section - Degreasing Experiment

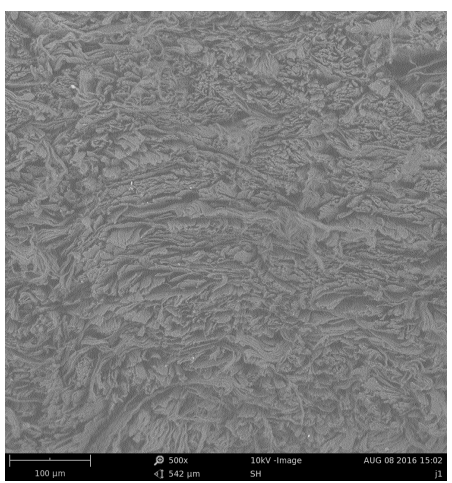

8. Cross section - Acetic acid treatment Experiment 


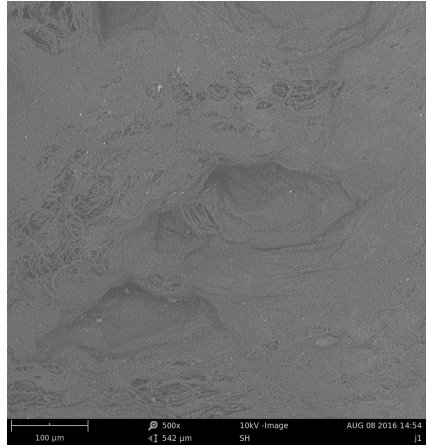

9. Grain surface - Urea Treatment

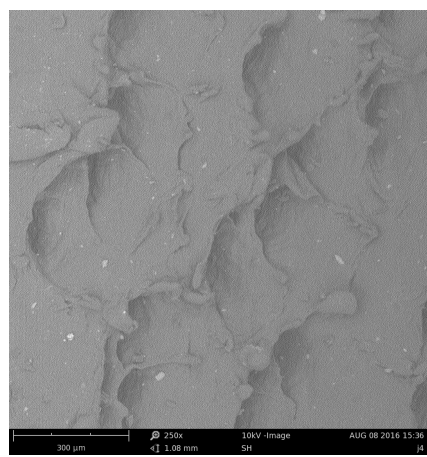

11. Grain surface - Integrated Acetic acid Treatment

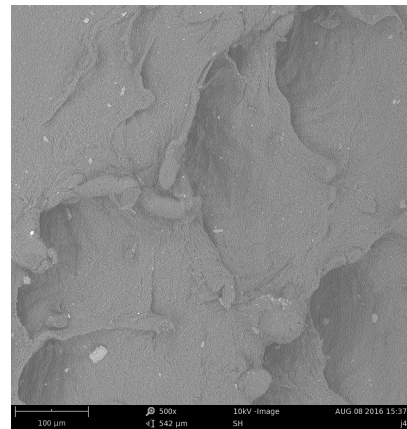

11. Grain surface - Integrated Urea Treatment

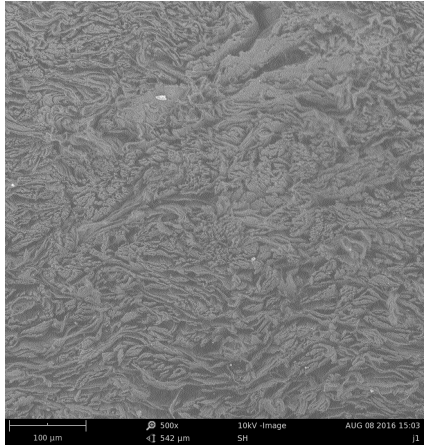

10. Cross section - Urea Treatment

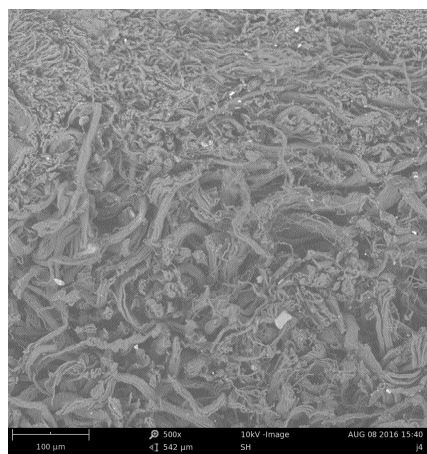

12. Cross section - Integrated Acetic acid Treatment

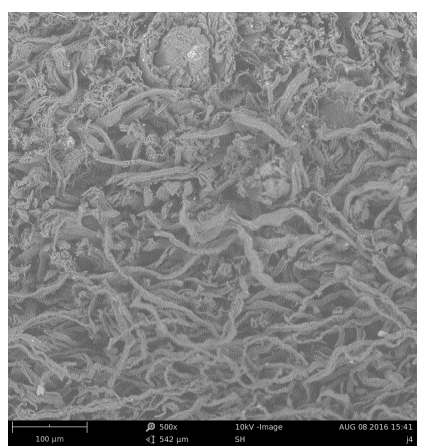

12. Cross section - Integrated Ureea Treatment

Figure 3. SEM of experimental leathers

\section{CONCLUSIONS}

The objective of improving water vapor permeability through enzymatic and chemical methods has been achieved without affecting other mechanical properties of leathers. When compared to acetic acid treatment, urea treatment has resulted in increased water vapor permeability. There was not much variation in strength properties between control and experiments with chemical and enzymatic treatments. Differences in water vapour permeability between crust and finished leathers were minimal. The approach provides an opportunity to improve the needed functional properties of leathers.

\section{REFERENCES}

1. Seligsberger, L., The Absorption of Water Vapor by Leather, J Am Leather Chem As, 1965, 60, 402-419. 
2. Mitton, R.G., The Diffusion of Water Vapor in Leather, J Soc Leath Tech Ch, 1955, 39, 385399.

3. Kanagy, J.R., Vickers, R.A., Factors Affecting the Water Vapor Permeability of Leather, $J$ Am Leather Chem As, 1950, 45, 211-241.

4. Landmann, A.W., Sofia, A., The Effect of Retannage and Nature of the Finish on Water Vapor Permeability and other Characteristics of the Finished Leather, J Soc Leath Tech Ch, 1970, 54, 3-26.

5. Seligsberger, L., Water Vapor Permeability of Leather and Leather like Sheet Materials: A New Approach, J Am Leather Chem As, 1975, 70, 3, 98-113.

6. Marshall, F.F., Williams, D., Permeability of Leather to Water Vapor, J Am Leather Chem As, 1946, 41, 6-19.

7. Taylor, M.M., Bailey, D.G., Feairheller, S.H., A Review of the Uses of Enzymes in the Tannery, J Am Leather Chem As, 1987, 82, 153-165.

8. Kanagy, J.R., Adsorption of Water Vapor by Untanned Hide and Various Leathers at $100^{\circ} \mathrm{F}$, J Am Leather Chem As, 1947, 42, 98-117.
9. Andrew, G.G., Gary, L.D., William, N.M., Chad, E.M., Unhairing with Proteolytic Enzymes Derived from Streptomyces griseus, J Am Leather Chem As, 2002, 97, 406-411.

10. Ludwig, S., Determination of the Surface Absorption of Water Vapor and Liquid Water by Leather and other Sheet Materials, J Am Leather Chem As, 1974, 69, 236-256.

11. Saryan, S.S., A Method of Determination of Water Vapor Absorption and Simultaneous Transmission through Shoe Upper Material, $J$ Am Leather Chem As, 1969, 64, 50-62.

12. Marcinkowska, E., Zuk, W., Water Vapor Permeability Measurement with the 'HY TESTER' Physical Simulator, I Am Leather Chem As, 2001, 96, 3, 94-102.

(C) 2017 by the author(s). Published by INCDTPICPI, Bucharest, RO. This is an open access article distributed under the terms and conditions of the Creative Commons Attribution license (http://creativecommons.org/licenses/by/4.0/). 